\title{
Environmental regulatory stringency and the market for abatement goods and services in China
}

\author{
Jing Lan \\ and \\ Alistair Munro
}

October 2014

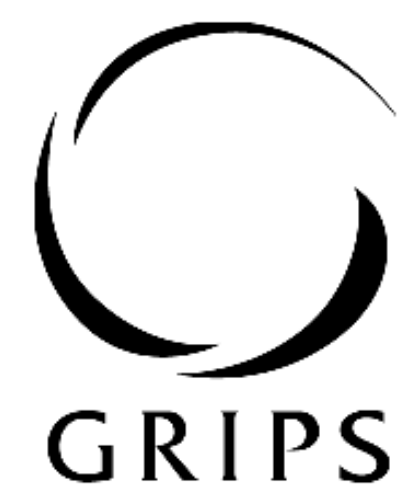

National Graduate institute

FOR POLICY STUDIES

National Graduate Institute for Policy Studies

7-22-1 Roppongi, Minato-ku,

Tokyo, Japan 106-8677 


\title{
Environmental regulatory stringency and the market for abatement goods and services in
}

China

\author{
Jing Lan \\ College of Public Administration, Nanjing Agricultural University, China
}

and

\begin{abstract}
Alistair Munro*
National Graduate Institute for Policy Studies (GRIPS), 7-22-1 Roppongi, Minato-ku, Tokyo, Japan 106-8677.

* corresponding author.
\end{abstract}

Abstract: We provide an examination of the linkage between environmental regulation stringency and the demand for and supply of abatement goods and services. To that end we construct a five-equation simultaneous model that links environmental regulation stringency to abatement output through various underlying simultaneous mechanisms. This system is then estimated using a panel of 679 eco-firms in 78 industrial Chinese cities during the implementation period of collection and use of pollution discharge fees (promulgated by the Chinese State Council) from 2003 to 2007. We find that higher fees are generally associated with higher abatement supply but for some industries - notably wastewater treatment - there is evidence of 'output restriction', meaning that higher charges lead to a reduction in supply for established firms.

JEL: J24;L60; Q56; 


\section{Introduction}

The aim of this study is to provide a rigorous examination of the linkage between environmental regulation stringency and the markets for abatement goods and services, often called 'eco-industries' (David and Sinclair-Desgagné (2005)). In so doing, we separate out two distinct mechanisms through which environmental regulation stringency may influence individual abatement output. The first may be labeled the direct effect and refers to the impact of environmental regulation stringency on an abatement supplier or eco-firm's output. The second one is the indirect effect which refers to the regulation induced effect on industrial abatement demand and its consequent impact on the individual abatement output of eco-firms. We construct a five-equation simultaneous model to examine the impact of environmental regulation stringency on abatement output and industrial abatement volume though various underlying simultaneous mechanisms. This simultaneous system is then tested by the panel data of 679 eco-firms in 78 industrial Chinese cities during the implementation period of Administration on the collection and use of pollution discharge fees (promulgated by the State Council) from 2003 to 2007.

Our main contributions are as follows. First, in most of the environmental economics literature, as David and Sinclair-Desgagné (2005) indicate pollution abatement is generally assumed to be set only by industrial polluters, based in turn on relevant regulatory, technological or output market considerations, but omitting the bilateral relationship with actual suppliers, eco-firms. In this study, we address the environmental regulation effect on individual abatement output of eco-firms. Our empirical study shifts the focus from industrial polluters to abatement suppliers.

Second, we quantify the overall effect of environmental regulation stringency on individual abatement supply by clarifying the directions of direct effect of environmental regulation stringency and regulation-induced indirect effect. Our empirical results show that a stricter environmental policy will increases the supply of Chinese eco-firms as a whole. However, the quantitative impact of regulation stringency on the individual output of firms varies between industrial sectors, as evidenced by the difference in results between from eco-firms in the sewage treatment sector and those in other abatement sectors. 
The following section will now briefly review the literature regarding the effect of environmental regulation stringency on abatement supply and demand. Section 3 next presents our theoretical model and its explanation. Section 4 proposes the econometric specification and describes the dataset. Section 5 displays the empirical estimates and discusses the results. The final section contains concluding remarks and policy implementation.

\section{Background}

Abatement services are often produced and developed in a specific industry, a so called "eco-industry" which sells abatement goods, services and technologies to other polluting industries. When industrial polluters put effort into abating emission, they have come to largely rely on a growing number of eco-firms for the delivery of abatement goods, services and technologies as indicated by Feess and Muehlheusser (1999), Greaker and Rosendahl (2008), David and Sinclair-Desgagné (2011). The development of eco-firms is determined by both the demand side and the supply side. Particularly, the market demand for environmentally sound technologies, products and services is often initialized and shaped by government promotion and industrial environmental performance requirements (Liu et al. 2006). We call this effect as the regulation-induced demand effect. As for the supply side, the environmental policy is likely to affect an eco-firm's investment and output decisions and price setting. According to David et al. (2011) for instance, a stricter environmental policy will reduce the price-elasticity of abatement demand. This acts as a signal that gives an incentive to eco-firms to adjust their outputs and prices.

There exists a well-developed strand of the environmental economics literature analyzing the strategic application of environmental regulation. The majority of this literature focuses on testing the Porter hypothesis and examining industrial polluters' abatement effort as a response to environmental regulations, in which abatement is assumed to be set only by polluter. For example, Wang (2002) empirically tests the pollution abatement efforts of Chinese industries in response to pollution regulations and the results show that plant-level expenditures on end-of-pipe wastewater treatment are strongly responsive to the pollution charges. The estimated elasticities of operation cost and new investment with respect to pollution price are 65 and 27\%, respectively. Backer (2005) investigate the effects of the US Clean Air Act on abatement capital expenditures and operating costs of manufacturing plants in the USA. His results show that heavy emitters of the "criteria" air pollutants that were subject to 
more stringent regulation generally had higher abatement expenditures. Requate and Unold (2003) investigate incentives to adopt advanced abatement technology and show that taxes provide stronger incentives than permits, auctioned and free permits offer identical incentives, and standards may give stronger incentives than permits. Feess and Muehlheusser $(1999,2002)$ integrated the eco-industry into the framework of strategic environmental policy, and examine whether tighter environmental regulation may benefit a trade nation by deriving the optimal environmental policy from a national point of view and show that the presence of eco-industry can lead to a national leadership in pollution control.

In the studies referred to above, the regulated eco-industry acts as a passive instrument for pollution control by government; none of them explicitly address the consequence for the eco-industry itself of stringent environmental regulation. Recently, economists have begun to examine the precise relationship between environmental regulations and the market for abatement goods and services. Greaker (2006) models the abatement sector as consisting of several imperfectly competitive firms. Tighter pollution regulation makes the sector more competitive and lowers markups. He finds conditions under which pollution regulation increases competitiveness between eco-firms. David and Sinclair-Desgagné (2005) consider how different policy instruments-emission tax, emission standards and voluntary agreements - can affect the abatement efforts by polluters and the price of abatement goods and services (and so affect the outputs of eco-firms).

More recently, David et al. (2011) address the consequence of environmental regulationinduced competition between eco-firms and indicate that environmental policy is likely to have impact on abatement output by influencing the entry and exit of abatement suppliers (see Figure 1 below which shows the demand for abatement services, A as a function of price, $p$ and regulatory strictness, $\gamma$ ). A stricter environmental policy (increasing from $\gamma_{0}$ to $\gamma_{1}$ ) will cause a parallel upwards shift of the inverse demand function (more demand for abatement at a given price) which is labeled as $p(\gamma, A)$ in the diagram. In addition, the inverse demand function becomes steeper as the environmental policy gets more stringent because demand becomes more inelastic. As shown in Figure 1, a stricter environmental policy generates a clockwise rotation of the inverse demand function. In their theoretical model, an eco-industry is assumed to be an oligopolistic industry with free entry. When eco-firms strategically increase their price through output restriction as a response to the reduced price elasticity of abatement demand, 
the expected higher profits attract new suppliers, which may result in a "business stealing effect" (Mankiw and Whinston (1986)) for existing suppliers. Note that more inelastic demand leads to lower output for existing firms, firm revenue increases in their model

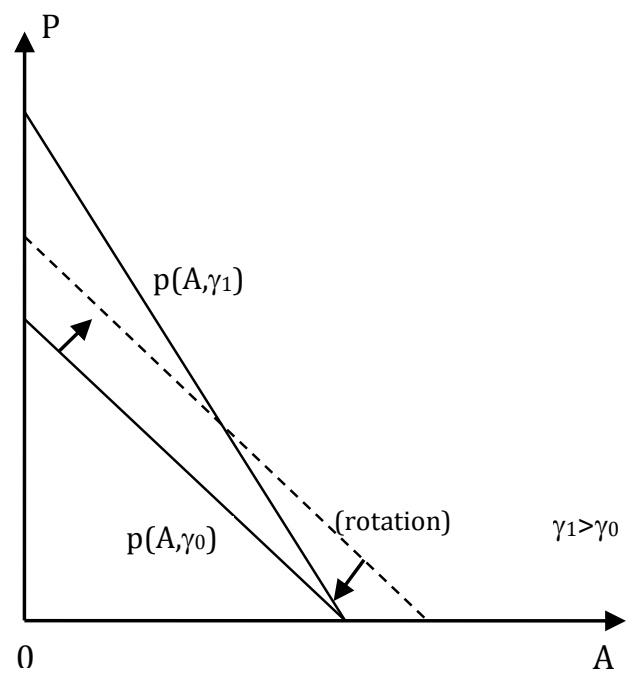

Figure 1. The impact of a stricter environmental policy on the abatement demand curve

As for the impact of a stricter environmental policy on abatement demand, David et al. point out that the total abatement demand always goes up when the delivery of abatement goods and services exhibits decreasing returns to scale. Figure 2 illustrates the aggregate equilibria on the abatement market when the cost of making abatement goods and services is convex $\left(G^{\prime \prime}(x)>0\right)$. When the environmental regulation is tightened (indicated by the higher levy charge of pollution), the marginal revenue curve rotates towards the right due to the rotation of the inverse demand curve and the increase in the number of eco-firms $m\left(m_{0}<m_{1}\right)$. The marginal cost curve, in contrast, may tilt to the right or to the left, as $\mathrm{m}$ increases while the individual marginal cost rotates to the right (since $G^{\prime}(A / m)$ decreases for any given $A$ ). In all cases, however, the quantity of abatement goods and services finally delivered $A_{1}$ is larger than $A_{0}$. 


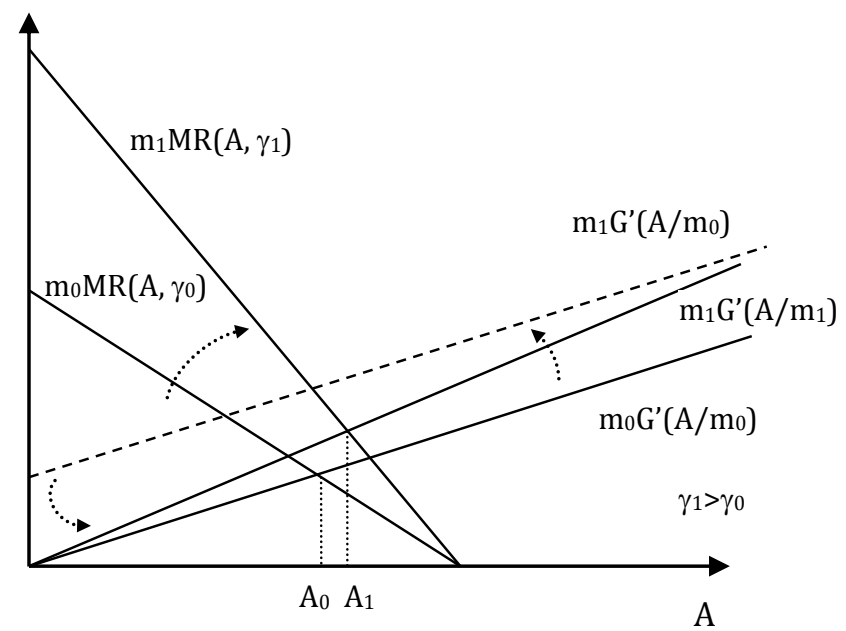

Figure 2. The impact of a stricter environmental policy on the equilibrium of the abatement market $\left(G^{\prime \prime}(a)>0\right)$

The basic idea is inspired by the theory in David et al. (2011) just described, but the intuitive argument extends to other contexts. For instance, a monopolist facing no threat of entry, will also face two impacts on the demand curve from an increase in regulatory strictness.

Empirically, the problem is that there are many channels though which environmental regulation stringency can affect abatement. For instance, regulation stringency itself can be affected by fast emission growth, economic growth and so on. Therefore, we need to use a simultaneous equations approach to examine the impact of a more stringent environmental policy on both the individual output of eco-firms and industrial abatement demand.

\section{Model Scheme.}

Figure 3 outlines the basic structural equation model (SEM) (with causation indicated by arrows). In it we show the potentially complex interactions between the individual supply of eco-firms $(x)$, local abatement demand $(A)$, industrial emissions $(E)$, local environmental stringency $(\gamma)$ and local economic output of goods and services $(Y)$. It enables us to account for various potential correlations between environmental regulation stringency and abatement supply and demand through the intermediation of the other economic characteristics. The numbers marked besides the arrows correspond to the equation numbers in system (1) shown 
later in the section. Note the identifying assumptions that the individual eco-firm's output does not determine other variables; that local environmental stringency only has an indirect effect on industrial output (through its effect on abatement and emissions) and that abatement has no direct effect on stringency.

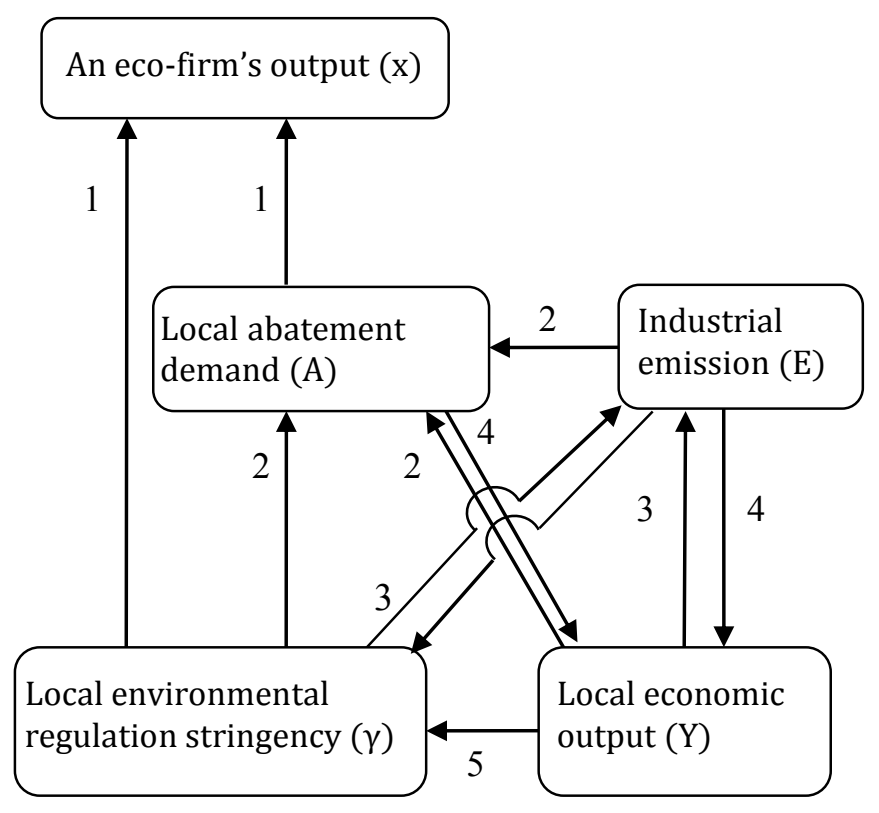

Figure 3 The schema for the linkage between an eco-firm's output and regulation stringency

We define the following variables (where $\mathrm{j}$ : indicator for eco-firm, i: indicator for city, $\mathrm{t}$ : indicator for year):

$\mathrm{x}_{\mathrm{jit}}$ : abatement output of the eco-firm

$A_{i t}^{L}$ : local abatement demand

$A_{i t}^{O}$ : outside abatement demand

$\gamma_{\text {it }}$ : environmental regulation stringency

$Y_{\text {it: }}$ total real GDP

$\Psi_{\mathrm{jit}}$ : vector of firm-level characteristics including a firm's size, R\&D expenses, advertisement expenses, export volume, and ownership status

$\Omega_{\mathrm{it}}$ : industrial capital-labor ratio

$\mathrm{K}_{\mathrm{it}}:$ total capital stock employed in industrial production

$\mathrm{L}_{\mathrm{it}}:$ total labor employed in industrial sectors

$\mathrm{E}_{\mathrm{it}}$ : original industrial emission without abatement

$\mathrm{HCl}_{\mathrm{it}}$ : industrial human capital intensity

$\mathrm{TECH}_{\mathrm{it}}$ : technological and scientific expenses by local government 
$\mathrm{E}_{\mathrm{it}-1}^{\text {net }}$ : lagged emission with abatement

Hedu $_{i t}$ : city human capital level

POPden $_{\text {it }}$ : population density

$\mathrm{UNemp}_{\mathrm{it}}$ : unemployment rate

Consequently, the relationship between the environmental regulation stringency and the output of an eco-firm is based on the following five- equation simultaneous system.

$$
\begin{aligned}
& \mathrm{x}_{\mathrm{jit}}=\mathrm{f}\left(\mathrm{A}_{\mathrm{it}}^{\mathrm{L}}, \mathrm{A}_{\mathrm{it}}^{\mathrm{O}}, \gamma_{\mathrm{it}}, \mathrm{Y}_{\mathrm{jit}}\right) \\
& \mathrm{A}_{\mathrm{it}}^{\mathrm{L}}=\mathrm{a}\left(\mathrm{Y}_{\mathrm{it}}, \mathrm{E}_{\mathrm{it}}, \gamma_{\mathrm{it}}, \mathrm{HCI}_{\mathrm{it}}, \mathrm{TECH}_{\mathrm{it}}\right) \\
& \mathrm{E}_{\mathrm{it}}=\mathrm{e}\left(\mathrm{Y}_{\mathrm{it}}, \Omega_{\mathrm{it}}, \gamma_{\mathrm{it}}\right) \\
& \mathrm{Y}_{\mathrm{it}}=\mathrm{y}\left(\mathrm{K}_{\mathrm{it}}, \mathrm{L}_{\mathrm{it}}, \mathrm{E}_{\mathrm{it}}, \mathrm{A}_{\mathrm{it}}^{\mathrm{L}}\right) \\
& \gamma_{\mathrm{it}}=\mathrm{t}\left(\mathrm{E}_{\mathrm{t}-1}^{\mathrm{net}}, \mathrm{Y}_{\mathrm{it}}, \mathrm{Hedu}_{\mathrm{it}}, \text { POPden }_{\mathrm{it}}, \mathrm{UNemp}_{\mathrm{it}}\right)
\end{aligned}
$$

In the next sub-section we consider each of the equations in more detail and provide a justification for the identifying restrictions.

\subsection{Abatement output}

There are three sets of determinants of an eco-firm's output in the first equation of system (1).

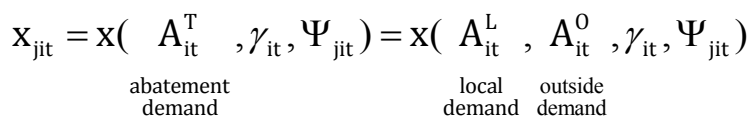

The first set is the total market demand $\left(A_{i t}^{\top}\right)$ an eco-firm faces, including local abatement demand and demand outside the city in which it is located. The local demand can be split into industrial demand and public consumption. The local abatement demand mainly depends on industrial need for pollution abatement in contemporary China. In the large majority of urban and rural areas, public consumption is not a significant factor (Liu, 2006; Martens, 2006). In line with standard theory, we expect that a firm's supply of a certain good is positively related to market demand, thus we might expect market demand for abatement to increase an eco-firm's output $\left(x_{A}>0\right)$. As for demand outside the city $\left(A_{i t}^{\top}\right)$, since we cannot observe this demand directly, we use transportation volume as a proxy for the possibilities for serving other markets (trancost). Lower transportation volume may mean less opportunity for exports as well as fewer imports into the city so we have no clear prior on the sign of the impact of this variable. 
The second set of determinants is the pollution control policy. The direct regulatory effect captures the effect of stringency on an eco-firm's output. As indicated in section two, a strict environmental policy signals to the eco-firms that the polluters have become less sensitive to price of abatement goods and services, which directly motivates eco-firms to increase their price through output restriction. This attracts a larger number of abatement suppliers while possibly inducing each one of them to produce less at equilibria. So, tighter regulation induces a reduction in individual output. Hence we expect a negative coefficient for this term, which means $x_{\gamma}<0$.

The third set of determinants is the firm's own characteristics $\left(\Psi_{\mathrm{jit}}\right)$, which include size, R\&D expenses, advertisement expenses, export volume, and ownership status, etc. For some of these we have no clear priors, but for some, such as firm size (=employment) we expect a positive relationship with the supply of abatement services.

\subsection{Industrial abatement volume}

In the second equation, the demand for abatement is determined by local economic output, the scale of industrial emission and the regulatory environment. Emissions, $\mathrm{E}_{\mathrm{it}}$ here are the initial emission generated in the industrial production process. It affects the emission volume that must be abated $\left(A_{i t} \leq E_{i t}\right)$ (and it turn may be affected by other factors, see section 3.3 below). As indicated by Panayotou (1997), economic output $\left(Y_{i t}\right)$ creates the conditions for social abatement by raising the demand for improved environmental quality and makes the resources available for supplying it. Hence, we expect that the higher the economic output, the greater the demand for abatement.

Besides $Y_{i t}, E_{i t}$ and $\gamma_{i t}$, we also introduce industrial human capital level and R\&D capacities into the abatement equation. As Lan and Munro (2013) indicate, environmental compliance of industrial polluters is significantly driven by human capital level. An industrial polluter with high human capital level is more likely to install abatement equipment or purchase abatement services. Turning to R\&D capacities, abatement technologies and its transformation into industrial application are greatly determined by technological and scientific expenditure of the local government.

$$
A_{i t}=a\left(Y_{i t}, E_{i t}, Y_{i t}, H C l_{i t}, T E C H_{i t}\right)
$$




\subsection{Industrial emissions}

Grossman and Kruger (1991), distinguish between three factors that can affect emissions: scale, industrial composition and technique effects. Other things kept unchanged, an economy with a larger production scale emits more pollution, so we expect a positive coefficient for scale or $\mathrm{Y}_{\text {it. }}$. The composition effect is often represented by the capital to labor ratio $(\mathrm{k} / \mathrm{l})$ as in Copeland and Taylor (1994), Antweiler et al. (2001), Cole and Elliot (2003) and Cole (2004). We expect a city to have a relatively less polluting industrial composition when its $\mathrm{k} / \mathrm{l}$ ratio is lower. $\mathrm{A}$ higher technique leads to a pollution intensity reduction; most previous studies use environmental regulation stringency as proxy for this effect. In our case the technique effect is captured by $\gamma$. Holding other factors constant, we expect tighter environmental policy to reduce emissions.

\subsection{Economic output}

We suppose real output $(\mathrm{Y})$ is a positive function of the stock of conventional factors of production, labor $(\mathrm{L})$ and capital $(\mathrm{K})$, and the ability to generate industrial emissions. Similar to most standard theories, we expect $Y_{L}>0, Y_{K}>0, Y_{E}>0$. In general, increased investment in abatement activity reduces productive investment and hampers economic growth (Barbera and McConnell, 1990; Gray and Shadbegian, 2003). But the presence of innovations in pollution abatement technology may reconcile (regulated) economic growth with the protection of the ecosystem (Andreoni and Levinson, 2001; Yang et al.,2012). Hence we are uncertain about the sign of $\mathrm{Y}_{\mathrm{A}}$.

\subsection{Environmental regulation stringency}

As discussed by Boyer and Laffont (1999), and the essays collected in Stavins (2004), the design of environmental policy is subject to pressures from public opinion and industrial lobbies. Firstly, if the emission is adjusted annually, the determination should include the emission level of last year. Second, we postulate that the regulatory stringency is also likely to be determined by local economic growth. There is likely to be a positive linkage between a region's economic prosperity and the stringency of its regulations (Dasgupta et al., 1995, He 2006). Thus, we expect that $p_{\gamma}>0$. Following the reasoning of Cole et al. (2008) and Lan et al. (2012), everything else equal, we expect a region with a high unemployment rate will tend to have relatively lax environmental 
regulations and we expect a negative coefficient for the unemployment rate (UNemp). Given the same income and population level, higher population density intensifies the marginal damage of pollution. We also include population density as a determinant for environmental regulation stringency and anticipate $\gamma_{\text {popden }}>0$. Furthermore, we expect $\gamma_{h}>0$ as suggested by Lan and Munro (2013): a region with greater proportion of highly educated population might have stricter environmental regulation since more educated people are more likely to be aware of environmental quality and its consequences and more efficient in making complaints to force regulators to tighten environmental policy.

\section{Empirical specification and data choice}

Follow the method applied by He (2006), we apply total differentiation to all five equations and divide each of them by their corresponding dependent variable. Then we get the following new system as shown below,

$$
\begin{aligned}
& \frac{\mathrm{dx}}{\mathrm{x}}=\frac{\partial \mathrm{x}}{\partial \mathrm{A}} \frac{\mathrm{A}}{\mathrm{x}} \frac{\mathrm{dA}}{\mathrm{A}}+\frac{\partial \mathrm{x}}{\partial \gamma} \frac{\gamma}{\mathrm{x}} \frac{\mathrm{d} \gamma}{\gamma}+\frac{\partial \mathrm{x}}{\partial \text { trancost }} \frac{\text { trancost }}{\mathrm{x}} \frac{\mathrm{dtrancost}}{\text { trancost }}+\frac{\partial \mathrm{x}}{\partial \Psi} \frac{\Psi}{\mathrm{x}} \frac{\mathrm{dx}}{\mathrm{d} \Psi} \\
& \frac{\mathrm{dA}}{\mathrm{A}}=\frac{\partial \mathrm{A}}{\partial \mathrm{E}} \frac{\mathrm{E}}{\mathrm{A}} \frac{\mathrm{dE}}{\mathrm{E}}+\frac{\partial \mathrm{A}}{\partial \gamma} \frac{\gamma}{\mathrm{A}} \frac{\mathrm{d} \gamma}{\gamma}+\frac{\partial \mathrm{A}}{\partial \mathrm{Y}} \frac{\mathrm{Y}}{\mathrm{A}} \frac{\mathrm{dY}}{\mathrm{Y}}+\frac{\partial \mathrm{A}}{\partial \mathrm{HCI}} \frac{\mathrm{HCI}}{\mathrm{A}} \frac{\mathrm{dHCI}}{\mathrm{HCI}}+\frac{\partial \mathrm{A}}{\partial \mathrm{TECH}} \frac{\mathrm{TECH}}{\mathrm{A}} \frac{\mathrm{dTECH}}{\mathrm{TECH}} \\
& \frac{\mathrm{dE}}{\mathrm{E}}=\frac{\partial \mathrm{E}}{\partial \mathrm{Y}} \frac{\mathrm{Y}}{\mathrm{E}} \frac{\mathrm{Y}}{\mathrm{Y}}+\frac{\partial \mathrm{E}}{\partial \gamma} \frac{\gamma}{\mathrm{E}} \frac{\mathrm{d} \gamma}{\gamma}+\frac{\partial \mathrm{E}}{\partial \Omega} \frac{\Omega}{\mathrm{E}} \frac{\mathrm{d} \Omega}{\Omega} \\
& \frac{\mathrm{d} Y}{\mathrm{Y}}=\frac{\partial \mathrm{Y}}{\partial \mathrm{A}} \frac{\mathrm{A}}{\mathrm{Y}} \frac{\mathrm{dA}}{\mathrm{A}}+\frac{\partial \mathrm{Y}}{\partial \mathrm{K}} \frac{\mathrm{K}}{\mathrm{Y}} \frac{\mathrm{dK}}{\mathrm{K}}+\frac{\partial \mathrm{Y}}{\partial \mathrm{L}} \frac{\mathrm{L}}{\mathrm{Y}} \frac{\mathrm{dL}}{\mathrm{L}}+\frac{\partial \mathrm{Y}}{\partial \mathrm{E}} \frac{\mathrm{E}}{\mathrm{Y}} \frac{\mathrm{dE}}{\mathrm{E}} \\
& \frac{\mathrm{d} \gamma}{\gamma}=\frac{\partial \gamma}{\partial \mathrm{E}_{\mathrm{t}-1}^{\text {net }}} \frac{\mathrm{E}_{\mathrm{t}-1}^{\text {net }}}{\gamma} \frac{\mathrm{d} \gamma}{\gamma}+\frac{\partial \gamma}{\partial \mathrm{Y}} \frac{\mathrm{Y}}{\gamma} \frac{\mathrm{dY}}{\mathrm{Y}}+\frac{\partial \gamma}{\partial \text { Hedu }} \frac{\text { Hedu }}{\gamma} \frac{\mathrm{dHedu}}{\text { Hedu }}+\frac{\partial \gamma}{\partial \text { POPden }} \frac{\partial \text { POPden }}{\gamma} \frac{\mathrm{dPOPden}}{\text { POPden }}+\frac{\partial \gamma}{\partial \text { Unemp }} \frac{\text { Unemp }}{\gamma} \frac{\mathrm{dUnemp}}{\text { Unemp }}
\end{aligned}
$$

This adjustment transforms each variable in system (1) into its growth rate. We estimate the full structural model based on system (2), using the approximation that $\ln ((z+d z) / z) \approx d z / z$ to specify each equation with all variables in logarithms form as shown in system (3). In system (3), we identify four endogenous variables in this system: $\ln A_{i t}, \ln E_{i t}, \ln Y_{i t}$ and $\ln \gamma_{i t}$. The eight citylevel exogenous variables are $\ln \mathrm{HCl}, \ln T E C H, \ln \Omega, \ln K, \operatorname{lnL}$, InHedu, InPOPden and InUnemp and one predetermined variable is $\operatorname{lnE}_{\mathrm{t}-1}{ }^{\text {net }}$, the firm-level variables are assumed to be exogenous since they are not correlated with city level characteristics. The system is over-identified in terms of order condition and rank condition. 


$$
\begin{aligned}
& \ln x_{j i t}=a_{x}^{A} \ln A_{i t}+a_{x}^{g} \ln \gamma_{i t}+a_{x}^{\text {transcost }} \ln \operatorname{trancost} t_{i t}+a_{x}^{\mathrm{y}} \ln Y_{j i t}+u_{j i t}^{x}
\end{aligned}
$$

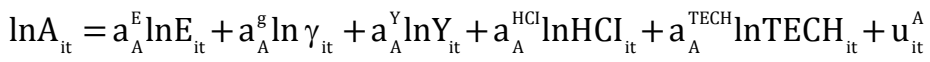

$$
\begin{aligned}
& \ln E_{\text {it }}=a_{E}^{\mathrm{Y}} \ln Y_{\text {it }}+a_{E}^{g} \ln \gamma_{\text {it }}+a_{E}^{g} \ln W_{i t}+u_{\text {it }}^{\mathrm{E}} \\
& \ln \mathrm{Y}_{\mathrm{it}}=\mathrm{a}_{\mathrm{Y}}^{\mathrm{A}} \ln \mathrm{A}_{\mathrm{it}}+\mathrm{a}_{\mathrm{Y}}^{\mathrm{K}} \ln \mathrm{K}_{\mathrm{it}}+\mathrm{a}_{\mathrm{Y}}^{\mathrm{L}} \ln \mathrm{L}_{\mathrm{it}}+\mathrm{a}_{\mathrm{Y}}^{\mathrm{E}} \ln \mathrm{E}_{\mathrm{it}}+\mathrm{u}_{\mathrm{it}}^{\mathrm{Y}}
\end{aligned}
$$

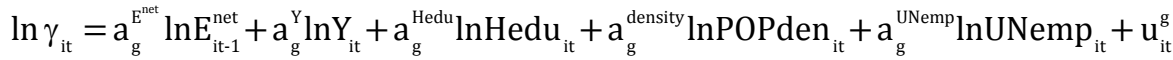

The coefficients represent the elasticities of dependent variables with respect to their independent variables. The indirect impact of regulation stringency on industrial abatement volume can be simply calculated by multiplying the elasticity of industrial abatement volume with respect to the economic determinant by the elasticity of this determinant with respect to regulation stringency. Hence, the total effect of regulation stringency on industrial abatement can be calculated as Eq. (4).

$$
\frac{\mathrm{dA}}{\mathrm{d} \gamma}=\underbrace{\alpha_{\mathrm{A}}^{\gamma}}_{\mathrm{I}}+\overbrace{\underbrace{\alpha_{\mathrm{A}}^{\mathrm{E}} \alpha_{\mathrm{E}}^{\gamma}}_{\mathrm{III}}+\underbrace{\mathrm{II}}_{\mathrm{V}}+\underbrace{\alpha_{\mathrm{Y}}^{\alpha_{\mathrm{Y}}^{\mathrm{E}} \alpha_{\mathrm{E}}^{\gamma}}}_{\mathrm{IV}}}^{\underbrace{}_{\text {IV }}}
$$

where I :direct effect of regulation stringency on industrial abatement volume;

II: indirect effect of regulation stringency on industrial abatement volume;

III: abatement chained by regulation induced emission reduction;

IV: economic growth chained by regulation induced emission;

$\mathrm{V}$ : abatement chained by emission induced economic output change

According to Eq. (4), the total effect of environmental policy stringency on industrial abatement volume decomposes into a direct and an indirect effect. The latter captures the effects through two channels, one is the impact of regulation stringency on emission and resultant impact of emission on industrial abatement; the other one is the impact of regulation stringency on emission and resultant impact of emission-induced economic growth on industrial abatement volume.

Similarly, we calculate the overall effect of regulation stringency on individual abatement output of eco-firms. The effect of regulation stringency on an eco-firm's output can be decomposed into a direct (regulation induced business-stealing effect) and an indirect effect (regulation induced demand effect). The indirect effect reflects the impact of regulation stringency on industrial abatement volume and resultant impact of industrial abatement volume on individual abatement output of eco-firms as shown in Eq.(5).

$$
\frac{\mathrm{dx}}{\mathrm{d} \gamma}=\alpha_{\mathrm{x}}^{\gamma}+\alpha_{\mathrm{x}}^{\mathrm{A}} \frac{\mathrm{dA}}{\mathrm{d} \gamma}=\underbrace{\alpha_{\mathrm{x}}^{\gamma}}_{\text {VI }}+\underbrace{\alpha_{\mathrm{x}}^{\mathrm{A}}(\underbrace{\alpha_{\mathrm{A}}^{\gamma}+\alpha_{\mathrm{A}}^{\mathrm{E}} \alpha_{\mathrm{E}}^{\gamma}+\alpha_{\mathrm{A}}^{\mathrm{Y}} \alpha_{\mathrm{Y}}^{\mathrm{E}} \alpha_{\mathrm{E}}^{\gamma}}_{\mathrm{VII}})}_{\text {VIII }}
$$

where VI : direct effect of regulation stringency on an eco-firm's output; 
VII: industrial abatement induced by reinforcement in environmental regulation stringency;

VIII: indirect effect of regulation stringency on an eco-firm's output.

The data used in this study is a panel dataset and so we introduce a fixed-effects models to control for possible industry and time effects inside each firm and each city. Another benefit of applying fixed effects models is that a SEM application with fixed effect allows us to control for unobserved heterogeneity while dealing with simultaneity. Since we need to account for both firm- and city-level fixed effects, we separately estimate each equation in the SEM (3). Besides the time-invariable specific effect, there may exist potential correlation between the residuals of different functions due to the inter-correlation between endogenous variables, which means $\operatorname{cov}\left(\varepsilon_{i}, \varepsilon_{j}\right) \neq 0$, where $i$ and $j$ indicate different sub-equations in the system. To get efficient estimates, we use two-step GMM-IV estimation to control the covariance matrix of the residuals of the system as a whole, where the endogenous variables are instrumented by all the exogenous variables. Specifically, we estimate the first equation by using a firm-level fixed effect and estimate the following four equations based on city-level fixed effects. In terms of the order condition and the rank condition, each equation in the system is over-identified. In addition, we also apply the system estimator of 3SLS to estimate the whole simultaneous model where the fixed effect of each firm and each city is removed by the first-difference transformation.

\subsection{Data and estimation}

To examine the regulatory effects on individual output of eco-firms and industrial abatement in China, we select the eco-firms from the Chinese industrial enterprises database (CIED) that supplies information on Chinese industrial enterprises above a designated size in China annually from 1996 to 2009. CIED are sample surveys, but they are representative, the total production quantity of surveyed industrial enterprises accounts for $95 \%$ of Chinese industrial production quantity. The firm-level data are compiled for 6 eco-industrial sectors for 5 years from 2003 to 2007, for a sample of 3395 observations. Owning to the use of one-lagged variables, the number of observations decreased to 2712. We adopt a traditional definition of eco-industrial sectors, including those sectors that provide products and services aiming at clean-up actions and remedial measures. At the 4-digit level, there are six eco-industries. They are environment protection-related industries of medical materials for environmental pollution treatment (2666); 
environmental pollution prevention equipment (3691); environmental supervision instruments and meters (4121); metal scraps and dross recycling and processing (4310); nonmetal scraps and oddment recycling and processing (4320); sewage water processing and recycling (4620).

The dataset we actually use covers the period from 2003 to 2007. The reason for choosing this period is twofold. First, though the surveys of industrial enterprises are conducted annually, the surveyed indicators are not consistent and appear to be missing in years immediately outside the chosen period. In fact 2003-2007 represents the longest unbroken interval that includes all the indicators required for this study. Secondly, the use of the selected period is also motivated by the desire to analyze recent trends of environmental regulations promulgated by the State Council in 2003. According to the documents for the Administration of the collection and use of pollution discharge fees, environmental regulations are tightening annually, which provide more variation in levy charges of pollutants.

Tables 1 summarizes the definitions and summary statistics of all variables, with details of sources provided in Appendix 1. Besides CIED, most of the city-level variables are obtained from Environment yearbook and Statistical yearbooks of key cities. The data for environmental regulation stringency is taken from National Development and Reform Commission for the years 2003-2007. Owing to the limitation of data, the industrial average wage is computed by using firm level wage from CIED for the selected cities. All nominal values are deflated into real value by the implicit price deflator of 1990 . 
Table 1 Statistical description of the data

\begin{tabular}{|c|c|c|c|c|c|c|}
\hline Variable & Observations & Unit & Mean & S.D. & Min & Max \\
\hline \multicolumn{7}{|c|}{ Firm-level variables } \\
\hline$x$ & 3390 & 1000 Yuan & 739.08 & 2152.05 & 41.870 & 69017.17 \\
\hline EXPORT & 3390 & 1000 Yuan & 2.867 & 16.381 & 0.000 & 374.93 \\
\hline $\mathrm{RD}$ & 3390 & 1000 Yuan & 0.231 & 1.264 & 0.000 & 32.57 \\
\hline SIZE & 3390 & & 135.95 & 204.508 & 11.000 & 2396.0 \\
\hline ADS & 3390 & Yuan & 462.25 & 324.300 & 0.000 & 806021.0 \\
\hline FOREIGN & 3390 & fraction & 0.134 & 0.341 & 0.000 & 1.000 \\
\hline HMT & 3390 & fraction & 0.060 & 0.246 & 0.000 & 1.000 \\
\hline STATE & 3390 & fraction & 0.065 & 0.238 & 0.000 & 1.000 \\
\hline COLLECTIVE & 3390 & fraction & 0.055 & 0.228 & 0.000 & 1.000 \\
\hline PRIVATE & 3390 & fraction & 0.412 & 0.492 & 0.000 & 1.000 \\
\hline \multicolumn{7}{|c|}{$\begin{array}{l}\text { City-level variables } \\
\Gamma\end{array}$} \\
\hline $\mathrm{SO}_{2}$ & 395 & Yuan/KG & 0.531 & 0.171 & 0.200 & 1.200 \\
\hline E Wastewater & 395 & Yuan/Ton & 0.921 & 0.353 & 0.200 & 1.970 \\
\hline $\mathrm{SO}_{2}$ & 395 & ton & 293.87 & 213.434 & 0.140 & 1313.80 \\
\hline A Wastewater & 395 & ton & 23546.70 & 13768.87 & 464.000 & 91260.0 \\
\hline $\mathrm{SO}_{2}$ & 395 & ton & 133.920 & 98.84 & 0.000 & 630.64 \\
\hline Wastewater & 395 & ton & 22496.12 & 17951.95 & 444.00 & 88072.0 \\
\hline transcost & 395 & million tons & 200.26 & 198.01 & 3.160 & 781.08 \\
\hline CAPstock & 395 & billion yuan & 320.89 & 343.18 & 12.150 & 1660.00 \\
\hline INDemp & 395 & thousand & 63.22 & 56.54 & 2.110 & 232.82 \\
\hline $\mathrm{HCl}$ & 395 & 1000 Yuan & 21.31 & 7.688 & 10.706 & 51.71 \\
\hline Hedu & 395 & percent & 0.068 & 0.048 & 0.008 & 0.301 \\
\hline TECH & 395 & million Yuan & 72.34 & 361.10 & 0.790 & 9074.23 \\
\hline POPdensity & 395 & per $\mathrm{km}^{2}$ & 430.77 & 314.24 & 120.86 & 2661.53 \\
\hline Unemp & 395 & $\%$ & 0.056 & 0.027 & 0.001 & 0.180 \\
\hline
\end{tabular}

\subsection{Data choice for environmental regulation stringency}

According to Kesidou and Demirel (2012), the stringency of environmental regulations is often proxied with abatement costs. In the presence of differences in regulatory stringency with respect to different kinds of pollutants, we choose charges for $\mathrm{SO}_{2}$ emission and treatment charges for industrial waste water as two proxies for local environmental regulation stringency.

With one-third of China's territory widely reported to be affected by acid rain, reducing $\mathrm{SO}_{2}$ emissions has been the key environmental target in China. By amending the 1987 Atmospheric Pollution Prevention and Control Act in August 1995, which newly added $\mathrm{SO}_{2}$ emission from coal 
combustion as the regulated pollutant, China has since 1996 started levying the charges for $\mathrm{SO}_{2}$ emissions in the so-called Two Control Zones based on the total quantity of emissions and at the rate of Yuan 0.20 per kilo of pollution equivalent (Yu, 2006). Since July 2003, this charge was applied nationwide and the charge rate was raised step by step. From 1 July 2005 onwards, the charge was applied at the level of Yuan 0.60 per kilo of pollution equivalent ${ }^{1}$. To help meet the energy-saving and environmental control goals set for the $11^{\text {th }}$ five-year economic plan, the Chinese government planned to double the charges for $\mathrm{SO}_{2}$ emissions in three steps from the existing level to Yuan 1.2 per kilo of pollutant equivalent within three years (The State Council, 2007). A key point is that local governments were allowed to raise pollution charges above the national levels, and thus levies over the sample period vary with the weight placed upon environmental protection by local authorities (Dasugpta, et al., 2001). Therefore, we use the actual local levy rate with respect to $\mathrm{SO}_{2}$ emissions to measure the actual local regulatory stringency faced by an industrial polluter.

To measure China's regulatory stringency of industrial waste water, we use an effective charge for industrial waste water treatment. As Smarzynska and Wei (2001) emphasize, many studies have had to rely on very broad proxies for environmental stringency, potentially causing measurement error. The availability of local treatment charges for industrial wastewater allows us to specify the stringency of regulations using a price-based policy instrument at the level of administration. We thereby avoid the use of the national level of levy rate for industrial wastewater ( 0.7 Yuan per kilo of pollutant equivalent) since it cannot measure the differences in regulatory stringencies due to the differences in local enforcement capacity. Following Wang (2002), we choose treatment charges for industrial wastewater as a proxy for environmental regulation stringency based on the following considerations. First, it reflects actual charges to firm's per unit of polluted wastewater and, thus, may reasonably measure the actual pollution

\footnotetext{
${ }^{1}$ Since 1999, Beijing charges 1.2 Yuan per kilo of pollution equivalent for $\mathrm{SO}_{2}$ emissions; Hangzhou and Jilin raised charges from 0.2 Yuan to 0.6 Yuan per kilo of pollution equivalent from 1 July 2003; Zhengzhou charged 0.5 Yuan per kilo pollution equivalent for $\mathrm{SO}_{2}$ emission from 1 July 2003 to July 2004 and the rate was raised to 0.6 Yuan per kilo pollution equivalent from 1 July 2005 (SEPA et al., 2003). Jiangsu province raised charges for $\mathrm{SO}_{2}$ emissions from Yuan 0.6 to Yuan 1.2 per kilo of pollution equivalent from 1 July 2007 onwards, three years ahead of the National schedule (Zhang, 2011).
} 
cost faced by an industrial polluter in a certain city ${ }^{2}$. Besides, it is set and collected by the local environmental protection bureaus and offices and the majority of charge revenue is used to invest in pollution prevention measures. So the treatment charge per unit of industrial wastewater in a Chinese city represents a policy-flavored intervention on the behalf of government. Furthermore, it varies across cities and over time. Part of the variation is due to differences in pollutant concentration standards, which are determined jointly by the national and the local governments. Part of the variation is also due to significant differences in enforcement capacity at the local level. However, we cannot rule out that the possibility that the variation in treatment charge of industrial wastewater is due to variations in efficiency rather than stringency. Against, this and considering the national widespread adoption of existing mature wastewater treatment technologies, we note that the difference in wastewater treatment efficiency may not be very large across cities.

It is worth re-emphasizing that the output of our eco-industries does not just cover waste-water treatment and $\mathrm{SO}_{2}$, but a wide variety of other environmental cleaning services. So that while the charge for wastewater and $\mathrm{SO}_{2}$ is a direct measure of stringency for some activities, in our model we are treating these two variables as proxies for the overall stringency of environmental regulation.

\section{Results}

Table 3 displays the results obtained using a two-step GMM estimator for panel data models with fixed-effects to estimate each equation in SEM (3). We can see that the overall fit of system is good. The fixed effects specification is found to be strongly favored by a Hausman test in all models. In most cases, the instrumental variables strongly correlate with the instrumented endogenous variables and the model passes the under-identification tests. The Kleibergen-Paap

\footnotetext{
${ }^{2}$ The average charge for urban sewage treatment was reported to be Yuan 0.7 per ton for 36 large and medium cities in China by the end of 2008, whereas the corresponding treatment cost is Yuan 1.1 per ton (NDRC, 2009; CAEP, 2009). In most of cities, the charge standard of wastewater treatment is set lower than its cost which indirectly reflects the difference in enforcement capacity of environmental regulation at the local level.
} 
rk LM statistics of under-identification tests suggest that we can reject the null hypothesis of under-identification, which means that the estimated equations are identified in that the instruments are correlated with the endogenous regressors. In most scenarios, the CraggDonald Wald F statistics compare favorably to the statistics reported in Stock and Yogo (2005), which suggest that we can comfortably reject the null hypothesis of weak instruments. The Sargan tests of over-identifying restrictions fail to reject the null hypothesis that the instruments are uncorrelated with the error term and that the specifications are correct.

The abatement output equation as shown in column (1) in Table 2 explains the determinants that influence the individual output of eco-firms. The coefficients on abatement demand $(\operatorname{In} A)$ are in the expected direction for $\mathrm{SO}_{2}$ and wastewater, implying the positive demand effect. As for regulatory stringency $(\ln \gamma)$, in both cases, it is positively associated with individual abatement output, but the effect of $\mathrm{SO}_{2}$ regulation stringency is insignificant; we will discuss their magnitudes in the next subsection. The positive sign of Iny implies that the induced outputrestriction effect does not apply here. This possibly reflects that the original data for output is in nominal form (i.e. it is revenue rather than output) and we deflate it. To the extent that firms raise price following stricter regulation this can lead to an increase in net revenue. As for the influence of other control variables, the coefficients are also measured with good precision and demonstrate strong and plausible effects. Turning to our firm-level variables, model (1) and model (6) in Table 2 show that the abatement supply of an eco-firm is a positive and significant function of EXPORT suggesting that exports-oriented firms tend to have more abatement supply, other things being equal. Not surprisingly, abatement output is a positive function of research and development expenditure, RD, suggesting that innovation within firms contribute to a firm's abatement supply. As for the ownership composition ${ }^{3}$, paid-in capital contributed by stateowned investors (STATE) is shown to have significantly negative impact on abatement supply by

\footnotetext{
${ }^{3}$ The State Statistical Bureau of China (SSB) assigns to each firm in the database a categorical variable indicating ownership status. Nevertheless, it is also possible to construct a continuous measure of ownership composition from the database by looking at the fraction of paid-in capital contributed by the state and private and foreign investors. This feature is useful when it comes to distinguishing between SOEs that are liquidated and those that are transferred to non-state hands.
} 
eco-firms. We cannot find significant coefficients for other ownership variables. Besides, the coefficient for transportation cost (transcost) is not statistically significant.

Model (2) and model (7) in Table 2 provides our estimates of industrial abatement volume with respect to industrial $\mathrm{SO}_{2}$ and industrial wastewater. Local economic growth $(\ln Y)$ is found to be significantly positive related to abatement volume of industrial wastewater emissions but it is estimated to be significantly negative associated with abatement volume of industrial $\mathrm{SO}_{2}$ emissions. The positive coefficients for $E_{i t}$ confirm that the abatement decision of industrial polluters is increasing in the scale of emissions. Regulatory stringency (LnY) is found to be positive, significant determinant of abatement demand. The variable $\operatorname{lnTECH}$ is estimated to be a positive but insignificant determinant of abatement volume of both pollutants. Finally, the variable $\mathrm{InHCl}$ is estimated to be a positive, significant determinant of industrial $\mathrm{SO}_{2}$ abatement, but an insignificant determinant of industrial wastewater, reflecting that human capital's impact on pollution abatement differs with respect to different pollutants. Human capital level has a significant effect on installment and absorption of advanced desulfurization technology, whilst its impact is insignificant on wastewater treatment technologies which have been widely applied in industrial production.

Equations (3) and (8) of Table 2 give the estimation results for industrial $\mathrm{SO}_{2}$ emissions and wastewater emission respectively. We get positive and significant coefficients for the scale effect and composition effect for both pollutants. The significantly negative coefficients of regulatory stringency variable $(\operatorname{In} \gamma)$ for both industrial $\mathrm{SO}_{2}$ emissions and industrial wastewater emissions reveal the fact that the levy charges of industrial $\mathrm{SO}_{2}$ and treatment charges of industrial wastewater does have deterrent effect on industrial emissions.

Equations labelled (4) and (9) display results obtained using output as the dependent variable. Not surprisingly capital stock (InCAPstock) and labor (InINDemp) are positively linked to output. Interestingly, abatement demand $(\operatorname{InA})$ for industrial wastewater is positively and significantly linked to output; while the abatement demand of $\mathrm{SO}_{2}$ emissions is negatively related to output. An intuitive explanation is that Chinese industrial polluters might take different attitudes towards the pollution abatement of wastewater and $\mathrm{SO}_{2}$ in response to a stricter environmental regulation. In fact, this result may be attributed to the widespread adoption of industrial wastewater abatement technology and an increasing number of urban sewage treatment centers in most Chinese cities. It is relatively easier to master the wastewater abatement 
technology and rearrange the combination of production inputs, hence industrial GDP growth can be obtained from a careful redesign of the production process induced by the need to comply with environmental regulations. The $\mathrm{SO}_{2}$ abatement technology, unlike the wastewater treatment technology, is not widely used. Particularly the industrial application of desulfurization technology is still at the experimental stage. When a firm allocates resources to abatement activities, this is conventionally believed to reduce productivity measured by ordinary outputs (Telle and Larsson, 2007). An increase in $\mathrm{SO}_{2}$ abatement expenditures would raise production cost and result in a negative impact on the value of total output. Finally, total emissions of both pollutants generated in industrial production ( $\operatorname{lnE}$ ) are found to be the significant determinants of total output.

In contrast to He's (2006) finding that the policy decision on the pollution control of industrial $\mathrm{SO}_{2}$ emissions is not based on the historical factors, both lagged industrial $\mathrm{SO}_{2}$ emission and industrial wastewater emissions $\left(\operatorname{lnE}_{\mathrm{t}-1}\right)$ are found to possess a positive, statistically significant, relationship with strictness of environmental regulation in both (5) and (10). The difference may possibly be attributed to our use of different measurements for environmental stringency. Output $(\ln Y)$ is found to be positively related to strictness of environmental regulations on both $\mathrm{SO}_{2}$ and wastewater, which is consistent with previous findings in Wang and Wheeler (1996) and He (2006), supporting the view that economic prosperity facilitates an increase of public demand for a better environment which will result in the intensification of environmental regulation stringency. As expected, we find a positive correlation between human capital level of city (Hedu, another human capital measure based on education) and stringency of environmental regulation, at least in terms of regulatory stringency of controlling industrial $\mathrm{SO}_{2}$ emissions. Finally, unemployment rate (UNEMP) is estimated to be a negative, significant determinant of regulatory stringency for both pollutants, whilst population density (POPdensity) is found to be an insignificant determinant of both $\mathrm{SO}_{2}$ regulation stringency and industrial wastewater regulation stringency. The significantly negative correlation between regulation stringency and the unemployment rate is in line with Gray and Deily's (1996) and Cole et al.'s (2008) findings that a high level of unemployment limits the scope for active environmental policies. 
Table 2 The simultaneous system estimation results (2-Step GMM estimation for simultaneous system, fixed effect, main Chinese industrial cities during the period 2003-2007)

\begin{tabular}{|c|c|c|c|c|c|c|c|c|c|c|}
\hline \multirow{3}{*}{ Variables } & \multicolumn{5}{|c|}{$\mathrm{SO}_{2}$} & \multicolumn{5}{|c|}{ wastewater } \\
\hline & (1) & (2) & (3) & (4) & (5) & (6) & (7) & (8) & (9) & (10) \\
\hline & $\ln x$ & $\ln A$ & $\ln \mathrm{E}$ & $\ln Y$ & $\ln \gamma$ & $\ln x$ & $\operatorname{In} A$ & $\ln \mathrm{E}$ & $\ln Y$ & $\ln \gamma$ \\
\hline $\ln A$ & $\begin{array}{l}0.223^{* * *} \\
(0.056)\end{array}$ & & & $\begin{array}{l}-0.017^{*} \\
(0.011)\end{array}$ & & $\begin{array}{l}0.539^{* * *} \\
(0.031)\end{array}$ & & & $\begin{array}{c}0.332^{*} \\
(0.189)\end{array}$ & \\
\hline $\ln Y$ & & $\begin{array}{l}-0.235^{*} \\
(0.127)\end{array}$ & $\begin{array}{l}0.066^{* * *} \\
(0.018)\end{array}$ & & $\begin{array}{l}0.209^{* * *} \\
(0.038)\end{array}$ & & $\begin{array}{l}0.360^{* * *} \\
(0.115)\end{array}$ & $\begin{array}{l}0.274^{* * *} \\
(0.076)\end{array}$ & & $\begin{array}{c}0.393^{*} \\
(0.223)\end{array}$ \\
\hline $\ln \Omega$ & & & $\begin{array}{l}0.094^{* *} \\
(0.045)\end{array}$ & & & & & $\begin{array}{c}0.136^{*} \\
(0.077)\end{array}$ & & \\
\hline $\ln \gamma$ & $\begin{array}{c}0.054 \\
(0.086)\end{array}$ & $\begin{array}{l}0.238^{* * *} \\
(0.074)\end{array}$ & $\begin{array}{l}-0.168^{* * *} \\
(0.055)\end{array}$ & & & $\begin{array}{c}0.176^{* *} \\
(0.085\end{array}$ & $\begin{array}{l}0.456^{* * *} \\
(0.135)\end{array}$ & $\begin{array}{l}-0.392^{* * *} \\
(0.130)\end{array}$ & & \\
\hline $\ln \mathrm{E}$ & & $\begin{array}{l}0.746^{* * *} \\
(0.278)\end{array}$ & & $\begin{array}{l}0.048^{* * *} \\
(0.023)\end{array}$ & & & $\begin{array}{l}0.886^{* * *} \\
(0.221)\end{array}$ & & $\begin{array}{c}0.134^{* *} \\
(0.067)\end{array}$ & \\
\hline lagged $\ln E^{\text {net }}$ & & & & & $\begin{array}{c}0.155^{* *} \\
(0.067)\end{array}$ & & & & & $\begin{array}{c}0.031^{* *} \\
(0.014)\end{array}$ \\
\hline InEXPORT & $\begin{array}{l}0.092^{* * *} \\
(0.027)\end{array}$ & & & & & $\begin{array}{l}0.115^{* * *} \\
(0.026)\end{array}$ & & & & \\
\hline $\ln R D$ & $\begin{array}{c}0.250^{* *} \\
(0.120)\end{array}$ & & & & & $\begin{array}{c}0.237 \\
(0.630)\end{array}$ & & & & \\
\hline InSIZE & $\begin{array}{l}0.213^{* * *} \\
(0.292)\end{array}$ & & & & & $\begin{array}{l}0.109^{* * *} \\
(0.021)\end{array}$ & & & & \\
\hline InADS & $\begin{array}{c}0.308^{* *} \\
(1.536)\end{array}$ & & & & & $\begin{array}{r}0.357^{*} \\
(0.187)\end{array}$ & & & & \\
\hline InFOREIGN & $\begin{array}{l}-0.032 \\
(0.074)\end{array}$ & & & & & $\begin{array}{l}-0.102 \\
(0.083)\end{array}$ & & & & \\
\hline InHMT & $\begin{array}{c}0.089 \\
(0.062)\end{array}$ & & & & & $\begin{array}{c}0.102 \\
(0.085)\end{array}$ & & & & \\
\hline InSTATE & $\begin{array}{l}-0.157^{* *} \\
(0.072)\end{array}$ & & & & & $\begin{array}{l}-0.148^{* *} \\
(0.070)\end{array}$ & & & & \\
\hline InCOLLECTIVE & $\begin{array}{l}-0.077 \\
(0.052)\end{array}$ & & & & & $\begin{array}{l}-0.107 \\
(0.068)\end{array}$ & & & & \\
\hline InPRIVATE & $\begin{array}{c}0.042 \\
(0.037)\end{array}$ & & & & & $\begin{array}{c}0.025 \\
(0.038)\end{array}$ & & & & \\
\hline Intranscost & $\begin{array}{c}0.135 \\
(0.887)\end{array}$ & & & & & $\begin{array}{l}-0.119 \\
(0.087)\end{array}$ & & & & \\
\hline InCAPstock & & & & $\begin{array}{l}0.292^{* * *} \\
(0.319)\end{array}$ & & & & & $\begin{array}{c}0.751^{* * *} \\
(0.238)\end{array}$ & \\
\hline InINDemp & & & & $\begin{array}{c}0.052^{* *} \\
(0.019)\end{array}$ & & & & & $\begin{array}{c}0.098 \\
(0.179)\end{array}$ & \\
\hline InTECH & & $\begin{array}{c}0.016 \\
(0.011)\end{array}$ & & & & & $\begin{array}{c}0.054 \\
(0.043)\end{array}$ & & & \\
\hline $\operatorname{lnHCl}$ & & $\begin{array}{c}0.004^{* *} \\
(0.002)\end{array}$ & & & & & $\begin{array}{c}0.016 \\
(0.012)\end{array}$ & & & \\
\hline InHedu & & & & & $\begin{array}{c}0.016^{* *} \\
(0.008)\end{array}$ & & & & & $\begin{array}{c}0.023 \\
(0.027)\end{array}$ \\
\hline InPOPdensity & & & & & $\begin{array}{c}0.025 \\
(0.029)\end{array}$ & & & & & $\begin{array}{c}0.034 \\
(0.014)\end{array}$ \\
\hline InUnemp & & & & & $\begin{array}{l}-0.189^{* *} \\
(0.108)\end{array}$ & & & & & $\begin{array}{l}-0.373^{*} \\
(0.202)\end{array}$ \\
\hline
\end{tabular}


Table 2 (Continued)

\begin{tabular}{|c|c|c|c|c|c|c|c|c|c|c|}
\hline \multirow{3}{*}{ Variables } & \multicolumn{5}{|l|}{$\mathrm{SO}_{2}$} & \multicolumn{5}{|c|}{ wastewater } \\
\hline & $(1)$ & (2) & (3) & (4) & (5) & (6) & (7) & (8) & (9) & (10) \\
\hline & $\operatorname{Ln} x$ & $\ln A$ & $\ln E$ & $\ln Y$ & $\ln \gamma$ & $\ln x$ & $\ln A$ & $\ln E$ & $\ln Y$ & Lny \\
\hline $\begin{array}{l}\text { Hausman } \\
\text { (fixed effect) }\end{array}$ & $\begin{array}{l}206.54 \\
(0.000)\end{array}$ & $\begin{array}{l}54.27 \\
(0.014)\end{array}$ & $\begin{array}{l}71.28 \\
(0.000)\end{array}$ & $\begin{array}{l}62.01 \\
(0.008)\end{array}$ & $\begin{array}{l}42.12 \\
(0.023)\end{array}$ & $\begin{array}{l}245.74 \\
(0.000)\end{array}$ & $\begin{array}{l}73.22 \\
(0.000)\end{array}$ & $\begin{array}{l}86.73 \\
(0.000)\end{array}$ & $\begin{array}{l}76.98 \\
(0.000)\end{array}$ & $\begin{array}{l}61.24 \\
(0.004)\end{array}$ \\
\hline Kleibergen-Paap & & & & & & & & & & \\
\hline $\begin{array}{l}\text { rk LM statistic } \\
\text { (Underidentifica } \\
\text { tion test ) }\end{array}$ & $\begin{array}{c}10.051 \\
\{0.092\}\end{array}$ & $\begin{array}{c}7.646 \\
\{0.083\}\end{array}$ & $\begin{array}{l}43.573 \\
\{0.000\}\end{array}$ & $\begin{array}{l}7.014 \\
\{0.092\}\end{array}$ & $\begin{array}{l}172.268 \\
\{0.000\}\end{array}$ & $\begin{array}{l}15.859 \\
\{0.044\}\end{array}$ & $\begin{array}{l}13.256 \\
\{0.033\}\end{array}$ & $\begin{array}{l}10.778 \\
\{0.088\}\end{array}$ & $\begin{array}{c}6.127 \\
\{0.127\}\end{array}$ & $\begin{array}{l}12.663 \\
\{0.013\}\end{array}$ \\
\hline $\begin{array}{l}\text { Cragg-Donald } \\
\text { Wald F statistic }\end{array}$ & & & & & & & & & & \\
\hline $\begin{array}{l}\text { (Weak } \\
\text { identification } \\
\text { test) }\end{array}$ & 30.708 & 45.34 & 6.205 & 16.886 & 101.307 & 19.540 & 11.540 & 7.336 & 12.208 & 106.526 \\
\hline $\begin{array}{l}\text { Sargan statistics } \\
\text { (system } \\
\text { identification) }\end{array}$ & $\begin{array}{c}5.814 \\
\{0.325\}\end{array}$ & $\begin{array}{c}2.214 \\
\{0.696\}\end{array}$ & $\begin{array}{c}2.325 \\
\{0.887\}\end{array}$ & $\begin{array}{l}2.750 \\
\{0.431\}\end{array}$ & $\begin{array}{c}1.223 \\
\{0.747\}\end{array}$ & $\begin{array}{c}5.928 \\
\{0.313\}\end{array}$ & $\begin{array}{c}5.216 \\
\{0.266\}\end{array}$ & $\begin{array}{c}8.310 \\
\{0.140\}\end{array}$ & $\begin{array}{c}4.151 \\
\{0.245\}\end{array}$ & $\begin{array}{c}1.245 \\
\{0.742\}\end{array}$ \\
\hline Observation & 2317 & 308 & 308 & 308 & 308 & 2317 & 308 & 308 & 308 & 308 \\
\hline
\end{tabular}

a. $^{* * *},{ }^{* *}$ and ${ }^{*}$ denote significance at $99 \%, 95 \%$ and $90 \%$, respectively

b. Equations (1) and (6) use firm fixed effects, and the reported standard errors are robust to heteroskedasticity and adjusted for clusters by cities. Other models use city fixed effect, and the reported standard errors are robust to heteroskedasticity.

c. The heteroskedasticity is corrected by the White's heteroskedasticity consistent covariance matrix.

d. The J-statistics is obtained from Sargan test of the validity of all instruments.

e. Reduction in the number of observations is due to the data transformation, such as lagged variable and logarithms form. 


\subsection{Policy simulation: The Effect of regulatory stringency}

In Tables 3 and 4 we calculate the direct, indirect and total impact of environmental regulation stringency on industrial abatement demand and an eco-firm's output by using the estimated coefficients as shown in Table 2. The effects and corresponding standard errors are computed using the delta method. From Table 3 below, we can see that the regulation stringency of both pollutants has a significant positive direct effect and a significant negative indirect effect on industrial abatement demand. Though the indirect effects are negative, the overall impacts of environmental regulation stringency on industrial abatement demand are estimated to be positive. Our results show that a $1 \%$ increase in the levy charge of industrial $\mathrm{SO}_{2}$ emission increases industrial $\mathrm{SO}_{2}$ abatement volume by $0.114 \%$; a $1 \%$ increase in the treatment charge of industrial wastewater will lead to an increase in industrial abatement volume by $0.091 \%$.

Table 3 The impact of environmental regulation stringency on industrial abatement demand

\begin{tabular}{|c|c|c|c|}
\hline \multirow{2}{*}{$\begin{array}{l}\text { Regulation stringency of } \\
\text { target pollutant }\end{array}$} & Direct effect & Indirect effect & Total effect \\
\hline & $\alpha_{A}^{\gamma}$ & $\alpha_{A}^{\mathrm{E}} \alpha_{E}^{Y}+\alpha_{A}^{Y} \alpha_{Y}^{\mathrm{E}} \alpha_{E}^{Y}$ & $\alpha_{A}^{Y}+\alpha_{A}^{\mathrm{E}} \alpha_{E}^{Y}+\alpha_{A}^{Y} \alpha_{Y}^{\mathrm{E}} \alpha_{E}^{Y}$ \\
\hline $\mathrm{SO}_{2}$ & $0.238^{* * *}$ & $-0.124^{* *}$ & $0.114^{* *}$ \\
\hline Wastewater & $\begin{array}{l}0.456^{* * *} \\
(0.108)\end{array}$ & $\begin{array}{l}-0.365^{* *} \\
(0.166)\end{array}$ & $\begin{array}{l}0.091^{* *} \\
(0.043)\end{array}$ \\
\hline
\end{tabular}

a. The effects and corresponding standard errors are computed by using delta method.

b. ${ }^{* * *},{ }^{* *}$ and ${ }^{*}$ denote significance at $99 \%, 95 \%$ and $90 \%$, respectively.

Turning to the effect of regulation stringency on individual supply as shown in Table 4, the direct effect of $\mathrm{SO}_{2}$ regulation stringency on an eco-firm's abatement supply is insignificant. This result implies that for $\mathrm{SO}_{2}$ a regulation-induced output restriction effect does not exist for our sample as a whole. Hence the overall effect is due to the indirect effect, implying that a $1 \%$ increase in the levy charge of industrial $\mathrm{SO}_{2}$ emission will lead to an increase in an eco-firm's output by $0.089 \%$. As for the regulation stringency of industrial wastewater, both the direct effect and demand effect are found to be significantly positive. A $1 \%$ increase in the treatment charge of industrial wastewater emission will result in a $0.225 \%$ increase in an eco-firm's abatement supply.

It is notable that the effect of regulation stringency on wastewater abatement output is estimated to be greater than that of $\mathrm{SO}_{2}$ regulation stringency on individual abatement output. 
In the abatement market, the majority of ready-made provided is wastewater related abatement goods and services, which may induce eco-firms to be more sensitive to environmental policy of wastewater emissions.

Table 4. The impact of environmental regulation stringency on individual abatement supply

\begin{tabular}{|c|c|c|c|}
\hline \multirow[t]{2}{*}{$\begin{array}{l}\text { Regulation stringency } \\
\text { of target pollutant }\end{array}$} & $\begin{array}{c}\text { Direct effect } \\
\text { (Output restriction } \\
\text { effect) }\end{array}$ & $\begin{array}{l}\text { Indirect effect } \\
\text { (Demand effect) }\end{array}$ & Total effect \\
\hline & $\alpha_{x}^{Y}$ & $\alpha_{x}^{\mathrm{A}}\left(\alpha_{A}^{\mathrm{E}} \alpha_{E}^{\gamma}+\alpha_{A}^{Y} \alpha_{\gamma}^{\mathrm{E}} \alpha_{E}^{\gamma}\right)$ & $\alpha_{\mathrm{x}}^{\gamma}+\alpha_{\mathrm{x}}^{\mathrm{A}}\left(\alpha_{A}^{\mathrm{E}} \alpha_{\mathrm{E}}^{\gamma}+\alpha_{A}^{Y} \alpha_{\gamma}^{\mathrm{E}} \alpha_{\mathrm{E}}^{\gamma}\right)$ \\
\hline $\mathrm{SO}_{2}$ & $\begin{array}{c}0.054 \\
(0.086)\end{array}$ & $\begin{array}{l}0.025^{*} \\
(0.014)\end{array}$ & $\begin{array}{c}0.079 \\
(0.097)\end{array}$ \\
\hline $\begin{array}{l}\text { Wastewater } \\
\text { emissions }\end{array}$ & $\begin{array}{l}0.176^{* * *} \\
(0.057)\end{array}$ & $\begin{array}{l}0.049^{* *} \\
(0.023)\end{array}$ & $\begin{array}{l}0.225^{* *} \\
(0.113)\end{array}$ \\
\hline
\end{tabular}

a. The effects and corresponding standard errors are computed by using the delta method.

b. $* * *, * *$ and $*$ denote significance at $99 \%, 95 \%$ and $90 \%$, respectively.

Generally speaking, a stricter environmental policy not only contributes to better industrial environmental performance but also increases the average individual abatement output of the whole eco-industry. In our dataset, the eco-industry includes 6 sectors. Since the function of abatement products varies tremendously across different eco-industrial sectors, the output decisions of eco-firms in each sector may be quite different in response to environmental regulation stringency. Hence, to clarify the relationship between environmental regulation and individual abatement output with respect to individual sectors, we divide the sample into 5 subsets according to their classified sectors. ${ }^{4}$ The results are shown in Table 5 and Table 6.

From the city-level regression results, we know that the overall regulation effects on abatement demand of industrial $\mathrm{SO}_{2}$ emission and industrial wastewater emission are 0.114 and 0.091 respectively. To see the magnitude of the regulation effect on the abatement output of different eco-industrial sectors, we calculate the direct effect and indirect effect (demand effect) and the total effect by using the coefficients obtained from Tables 5 and 6 . As shown in Table 7, in most scenarios, the direct effects are small; a stringent environmental policy can stimulate more individual abatement output. Being quite different from other sectors, a stringent environmental policy for controlling industrial wastewater decreases individual abatement output of sewage water processing and recycling sector (4620). From Table 7, we see that a $1 \%$

\footnotetext{
${ }^{4}$ Because of their small size and similarity, we merge 4310 and 4320 (metal scraps and dross recycling and processing (4310); nonmetal scraps and oddment recycling and processing (4320)).
} 
increase in treatment charges of industrial wastewater decreases the output of a sewage treatment factory by $0.117 \%$ in total.

This negative direct effect in the water treatment sector (4620) may reflect the presence of a business-stealing effect. It's relatively easier to operate a sewage treatment factory with technical backup, due to the availability of ready-made wastewater treatment technologies in abatement market. This lowers the threshold for market entry of operating sewage treatment business and attracts more entrants. Besides, China has stipulated policies to encourage private and foreign investment in wastewater treatment facilities. Jiang, and Zheng, 2010 for instance note high levels of entry in the adjacent water supply industry (4610) over our sample period. 
Table 5 Estimates for individual abatement output of eco-firms of different sectors based on $\mathrm{SO}_{2}$ regulation stringency (2-step GMM, fixed effect, main Chinese industrial cities during the period 2003-2007)

\begin{tabular}{|c|c|c|c|c|c|c|c|c|c|c|}
\hline \multirow{2}{*}{ Variables } & \multicolumn{10}{|c|}{ Sectors of eco-firms } \\
\hline & \multicolumn{2}{|c|}{2666} & \multicolumn{2}{|c|}{3691} & \multicolumn{2}{|c|}{4121} & \multicolumn{2}{|c|}{$4310 / 4320$} & \multicolumn{2}{|c|}{4620} \\
\hline InA (industrial $\mathrm{SO}_{2}$ abatement) & $0.708^{* *}$ & ${ }^{*}(0.337)$ & $0.255^{* *}$ & $(0.119)$ & $0.218^{* *}$ & $(0.102)$ & $0.195^{* * *}$ & ${ }^{*}(0.769)$ & $0.355^{* * *}$ & ${ }^{*}(0.116)$ \\
\hline $\ln \gamma\left(\mathrm{SO}_{2}\right.$ regulation $)$ & 0.049 & $(0.126)$ & 0.073 & $(0.081)$ & $0.051^{*}$ & $(0.027)$ & -0.067 & $(0.182)$ & -0.025 & $(0.058)$ \\
\hline InEXPORT & $0.149^{*}$ & $(0.087)$ & $0.115^{* *}$ & $(0.054)$ & 0.291 & $(0.262)$ & 0.177 & $(0.126)$ & 0.240 & $(0.213)$ \\
\hline $\ln R D$ & 0.796 & (3.974) & $0.189^{*}$ & $(0.106)$ & -0.264 & $(0.584)$ & $0.527^{* *}$ & $(0.229)$ & 0.218 & $(0.286)$ \\
\hline InSIZE & 0.039 & $(0.071)$ & $0.366^{* *}$ & $*(0.064)$ & $0.512^{* *}$ & $(0.233)$ & 0.138 & (0.089) & 0.235 & $(0.174)$ \\
\hline InADS & 0.185 & (0.197) & $0.251^{* *}$ & ${ }^{*}(0.057)$ & 0.707 & $(0.614)$ & -0.845 & $(1.176)$ & -0.742 & $(0.713)$ \\
\hline InFOREIGN & -0.112 & $(0.739)$ & 0.098 & $(0.138)$ & 0.008 & $(0.028)$ & -0.110 & $(0.149)$ & $0.551^{* *}$ & * $(0.263)$ \\
\hline InHMT & $-0.248^{*}$ & (0.139) & 0.238 & $(0.175)$ & 0.084 & (0.169) & -0.103 & (0.153) & 0.224 & (0.183) \\
\hline InSTATE & -0.108 & $(0.292)$ & $-0.418^{* *}$ & $(0.202)$ & $0.408^{* * *}$ & ${ }^{*}(0.094)$ & -0.081 & $(0.431)$ & -0.078 & $(0.137)$ \\
\hline InCOLLECTIVE & $0.188^{* *}$ & $(0.086)$ & -0.059 & $(0.085)$ & $0.058^{* * *}$ & ${ }^{*}(0.093)$ & 0.080 & $(0.139)$ & -0.033 & $(0.122)$ \\
\hline InPRIVATE & 0.027 & (0.107) & 0.075 & $(0.056)$ & 0.094 & $(0.182)$ & -0.123 & (0.097) & 0.068 & $(0.069)$ \\
\hline Lntranscost & 0.469 & $(0.376)$ & 0.124 & (0.159) & 0.401 & $(0.316)$ & 0.132 & $(0.141)$ & $0.214^{*}$ & $(0.120)$ \\
\hline $\begin{array}{l}\text { Kleibergen-Paap rk LM statistic } \\
\text { (Underidentification test ) }\end{array}$ & 16.563 & $\{0.029\}$ & 14.032 & $\{0.063\}$ & 9.958 & $\{0.268\}$ & 9.902 & $\{0.272\}$ & 13.702 & $\{0.086\}$ \\
\hline $\begin{array}{l}\text { Cragg-Donald Wald F statistic } \\
\text { (Weak identification test) }\end{array}$ & 32.055 & & 22.035 & & 5.640 & & 11.030 & & 21.993 & \\
\hline $\begin{array}{l}\text { Sargan statistics } \\
\text { (system identification) }\end{array}$ & 10.083 & $\{0.184\}$ & 15.592 & $\{0.029\}$ & 6.892 & $\{0.440\}$ & 7.675 & $\{0.362\}$ & 6.770 & $\{0.453\}$ \\
\hline Observation & & 80 & 12 & & 14 & 44 & 74 & & & 02 \\
\hline
\end{tabular}

a. $* * *, * *$ and $*$ denote significance at $99 \%, 95 \%$ and $90 \%$, respectively.

b. The results are based on firm-level analysis in which the endogenous variables InA and Inp are instrumented by all system exogenous variables.

c. The variable $\mathrm{A}$ in this case is industrial $\mathrm{SO}_{2}$ abatement volume and the variable $\gamma$ is environmental regulation stringency of industrial $\mathrm{SO}_{2}$ emissions.

$\mathrm{d}$. The reported standard errors are robust to heteroskedasticity and adjusted for clusters by cities.

e. The J-statistics is obtained from Sargan test of the validity of all instruments.

f. Reduction in the number of observations is due to the data transformation, such as lagged variable and logarithms form. 
Table 6 Estimates for individual abatement output of eco-firms of different sectors based on industrial wastewater regulation stringency (2-step GMM, fixed effect, main Chinese industrial cities during the period 2003-2007)

\begin{tabular}{|c|c|c|c|c|c|c|c|c|}
\hline \multirow{2}{*}{ Variables } & \multicolumn{8}{|c|}{ Sectors of eco-firms } \\
\hline & 2666 & 3691 & & 21 & 4310 & 14320 & 46 & 20 \\
\hline InA (wastewater abatement) & $0.859^{* *}(0.437)$ & $0.822^{* * *}(0.183)$ & $0.608^{*}$ & $(0.298)$ & 0.208 & $(0.142)$ & $0.326^{* *}$ & $(0.134)$ \\
\hline Iny (wastewater regulation) & $0.127^{* * *}(0.033)$ & $0.279^{* *}(0.137)$ & $0.089^{*}$ & (0.046) & 0.082 & (0.091) & $-0.146^{* *}$ & $(0.073)$ \\
\hline InEXPORT & $-0.154^{* *}(0.078)$ & $0.120^{* *}(0.048)$ & -0.418 & $(0.337)$ & $0.306^{* *}$ & * $(0.117)$ & 0.203 & $(0.236)$ \\
\hline $\ln R D$ & $0.114 \quad(0.182)$ & $0.150 \quad(0.102)$ & -0.360 & (0.479) & $0.634^{* *}$ & ${ }^{*}(0.235)$ & 0.231 & $(0.286)$ \\
\hline InSIZE & $0.002^{* *}(0.001)$ & $0.329^{* * *}(0.067)$ & $0.586^{* *}$ & * & 0.099 & (0.163) & 0.272 & (0.166) \\
\hline InADS & $0.504^{* *}(0.232)$ & $0.267^{* * *}(0.052)$ & 0.641 & (0.927) & -0.157 & (0.169) & -0.734 & (0.787) \\
\hline InFOREIGN & $-0.372 \quad(0.277)$ & $0.163 \quad(0.117)$ & 0.404 & $(0.333)$ & -0.082 & (0.148) & $0.587^{* *}$ & $(0.231)$ \\
\hline InHMT & $-0.308^{* * *}(0.112)$ & $0.317 \quad(0.131)$ & 0.084 & $(0.169)$ & -0.103 & $(0.153)$ & 0.184 & $(0.242)$ \\
\hline InSTATE & $-0.324 \quad(0.359)$ & $-0.375 \quad(0.319)$ & $0.293^{* *}$ & * $(0.106)$ & 0.192 & $(0.237)$ & -0.082 & (0.127) \\
\hline InCOLLECTIVE & $0.188^{* *}(0.086)$ & $-0.096 \quad(0.129)$ & $0.129^{* *}$ & * & 0.112 & (0.142) & -0.119 & (0.113) \\
\hline InPRIVATE & $-0.054 \quad(0.081)$ & $0.044 \quad(0.058)$ & 0.061 & $(0.182)$ & -0.072 & (0.095) & 0.069 & $(0.088)$ \\
\hline Lntranscost & $0.533 \quad(0.342)$ & $0.034 \quad(0.155)$ & 0.401 & $(0.316)$ & 0.143 & (0.173) & 0.058 & (0.183) \\
\hline $\begin{array}{l}\text { Kleibergen-Paap rk LM statistic } \\
\text { (Underidentification test ) }\end{array}$ & $16.308\{0.037\}$ & $15.181\{0.056\}$ & 10.785 & $\{0.214\}$ & 15.865 & $\{0.044\}$ & 15.914 & $\{0.042\}$ \\
\hline $\begin{array}{l}\text { Cragg-Donald Wald F statistic } \\
\text { (Weak identification test) }\end{array}$ & 32.338 & 17.034 & 4.411 & & 30.233 & & 34.101 & \\
\hline $\begin{array}{l}\text { Sargan statistics } \\
\text { (system identification) }\end{array}$ & $5.503\{0.599\}$ & $14.002\{0.051\}$ & 9.228 & $\{0.237\}$ & 10.261 & $\{0.174\}$ & 4.294 & $\{0.745\}$ \\
\hline Observation & 280 & 1264 & & 44 & & 48 & 20 & 04 \\
\hline
\end{tabular}

a. $* * *, * *$ and $*$ denote significance at $99 \%, 95 \%$ and $90 \%$, respectively.

b. The results are based on firm-level analysis in which the endogenous variables InA and Inv are instrumented by all system exogenous variables.

c. The variable $A$ in this case is industrial wastewater abatement volume and the variable $\gamma$ is environmental regulation stringency of industrial wastewater emissions.

d. The reported standard errors are robust to heteroskedasticity and adjusted for clusters by cities.

e. The J-statistics is obtained from Sargan test of the validity of all instruments.

a. Reduction in the number of observations is due to the data transformation, such as lagged variable and logarithms form. 
Table 7 Regulation's effect on the abatement output of different eco-industrial sectors

\begin{tabular}{|c|c|c|c|c|c|c|}
\hline \multirow{3}{*}{$\begin{array}{l}\text { Eco- } \\
\text { industrial } \\
\text { Sectors }\end{array}$} & \multirow{3}{*}{$\alpha_{\mathrm{x}}^{\mathrm{A}}$} & \multirow{3}{*}{$\alpha_{A}^{\mathrm{E}} \alpha_{\mathrm{E}}^{\gamma}+\alpha_{A}^{Y} \alpha_{Y}^{\mathrm{E}} \alpha_{\mathrm{E}}^{\gamma}$} & \multicolumn{4}{|c|}{ Regulation effect on individual abatement output } \\
\hline & & & \multirow{2}{*}{$\begin{array}{c}\begin{array}{c}\text { Output } \\
\text { restriction } \\
\text { effect }\end{array} \\
\alpha_{\mathrm{x}}^{\gamma} \\
\end{array}$} & $\begin{array}{c}\text { Demand } \\
\text { effect }\end{array}$ & \multicolumn{2}{|c|}{$\begin{array}{l}\text { Total } \\
\text { effect }\end{array}$} \\
\hline & & & & $\alpha_{x}^{A}\left(\alpha_{A}^{E} \alpha_{E}^{\gamma}+\alpha_{A}^{Y} \alpha_{Y}^{E} \alpha_{E}^{\gamma}\right)$ & \multicolumn{2}{|c|}{$\alpha_{x}^{Y}+\alpha_{x}^{\mathrm{A}}\left(\alpha_{A}^{\mathrm{E}} \alpha_{E}^{\gamma}+\alpha_{A}^{Y} \alpha_{Y}^{\mathrm{E}} \alpha_{E}^{\gamma}\right)$} \\
\hline & \multicolumn{6}{|c|}{ Regulation stringency of industrial $\mathrm{SO}_{2}$} \\
\hline 2666 & $0.708^{* * *}(0.337)$ & $0.114^{* *}(0.058)$ & $0.049 \quad(0.126)$ & $0.081^{* *}(0.039)$ & 0.130 & $(0.098)$ \\
\hline 3691 & $0.255^{* *}(0.119)$ & $0.114^{* *}(0.058)$ & $0.073(0.081)$ & $0.029^{*} \quad(0.016)$ & 0.102 & $(0.086)$ \\
\hline 4121 & $0.218^{* *}(0.102)$ & $0.114^{* *}(0.058)$ & $0.051^{*}(0.027)$ & $0.024^{*} \quad(0.013)$ & 0.075 & $(0.051)$ \\
\hline $4310 / 4320$ & $0.195^{* * *}(0.769)$ & $0.114^{* *}(0.058)$ & $-0.067(0.182)$ & $0.022^{* *}(0.011)$ & -0.045 & $(0.037)$ \\
\hline \multirow[t]{2}{*}{4620} & $0.396^{* *}(0.194)$ & $0.114^{* *}(0.058)$ & $-0.025(0.058)$ & $0.057^{*} \quad(0.031)$ & 0.032 & $(0.023)$ \\
\hline & \multicolumn{6}{|c|}{ Regulation stringency of industrial wastewater } \\
\hline 2666 & $0.859^{* *}(0.436)$ & $0.091^{* *}(0.043)$ & $0.127^{* * *}(0.033)$ & $0.078^{* *}(0.038)$ & $0.205^{* *}$ & $(0.101)$ \\
\hline 3691 & $0.822^{* * *}(0.183)$ & $0.091^{* *}(0.043)$ & $0.279^{* *}(0.137)$ & $0.074^{* *}(0.035)$ & $0.353^{*}$ & $(0.177)$ \\
\hline 4121 & $0.608^{* *}(0.298)$ & $0.091^{* *}(0.043)$ & $0.089^{* *}(0.043)$ & $0.055^{*} \quad(0.028)$ & $0.144^{*}$ & $(0.076)$ \\
\hline $4310 / 4320$ & $0.208(0.142)$ & $0.091^{* *}(0.043)$ & $0.082(0.091)$ & $0.018 \quad(0.020)$ & 0.100 & $(0.142)$ \\
\hline 4620 & $0.326^{* *}(0.134)$ & $0.091^{* *}(0.043)$ & $-0.146^{* *}(0.073)$ & $0.029^{* *}(0.018)$ & $-0.117^{* *}$ & $(0.091)$ \\
\hline
\end{tabular}

a. The effects and corresponding standard errors are computed by using delta method.

b. ${ }^{* *}, * *$ and ${ }^{*}$ denote significance at $99 \%, 95 \%$ and $90 \%$, respectively. 


\section{Concluding remarks and policy implications}

Taking into account the fact that regulatory stringency may differ according to its target pollutants, this study investigates the changes of industrial abatement volume as well as individual output of eco-firms in response to the stringency of environmental regulation. On the basis of a panel dataset of 678 eco-firms in 78 Chinese industrial cities during the period 2003-2007, we estimate a 5 equation model to clarify the relationship between regulatory stringency and the output of ecoindustry firms.

The results have shown that a more stringent environmental regulation of both industrial $\mathrm{SO}_{2}$ and wastewater emissions, not only contribute to the improvement of industrial environmental performance but also extend a helping hand to the development of eco-firms. With respect to the regulatory impact on industrial abatement demand, although the indirect effect of regulation stringency on industrial abatement volume is negative, the overall effect is positive for both pollutants. Turning to the regulatory impact on individual abatement supply, we find that the effect of tighter $\mathrm{SO}_{2}$ regulation on individual abatement output is found to be insignificant; instead, $\mathrm{SO}_{2}$ regulation stringency can indirectly affect an eco-firm's output through its impact on industrial abatement demand. As for the environmental regulation stringency of industrial wastewater, we find that the treatment charges of industrial wastewater can directly and indirectly affect an ecofirm's output decision. In this regard, the sewage treatment stands out: the overall effect of tighter industrial wastewater regulation on the individual abatement output of existing firms in the sewage treatment sector is found to be negative, suggesting the existence of a "businessstealing effect" in the sewage treatment sector that surpasses the demand effect.

We finish on a note of caution. We see this paper as a first attempt to examine the complex linkage between regulatory stringency and demand for and supply of abatement for a large developing country such as China. In addition, we do not know whether the relationships estimated in this paper apply to pollutants other than $\mathrm{SO}_{2}$ and wastewater. These are currently the only two pollutants for which the data of industrial abatement volume are available in China. Inevitably, the study would be benefited from a richer dataset with more pollutants in a longer period. In time, such data may be forthcoming and so allowing more sophisticated analysis. 


\section{References}

Andreoni, J., \& Levinson, A. (2003). The Simple Analytics of the Environmental Kuznets Curve. Journal of Public Economics, 46(3), 269-286.

Antweiler, W., Copeland, B., \& Taylor, M. (2001). Is free trade good for environment? American Economics Review, 4, pp. 877-908.

Barbera, A., \& McConnell, V. (1990). The Impact of Environmental Regulations on Industry Productivity: Direct and Indirect Effects. Journal of Environmental Economics and Management, 18(1), 50-65.

Boyer, M., \& Laffont, J. (1999). Toward a Political Theory of the Emergence of Environmental Incentive Regulation. The RAND Journal of Economics, 30(1), 137-157.

Cao, J. D., Yang, J., \& Ge, C. (1999). $\mathrm{SO}_{2}$ Charge and Tax Policies in China: Experiment and Reform. In OECD (Ed.), Environmental Taxes: Recent Development in China and OECD Countries (pp. 233-257). Paris: OECD.

Cole, M. (2004). Trade, the pollution haven hypothesis and the environmental Kuznets curve: examining the linkage. Ecological Economics, 3, 71-81.

Cole, M., \& Elliott, R. (2003). Determining the trade-environment composition effect: the role of capital, labor and environmental regulations. Journal of Environment and management, 3, 363-383.

Cole, M., Elliot, R., \& Wu, S. (2008). Industrial activity and the environment in China: An industrylevel analysis. China Economics Review, 3, 393-408.

Copeland, B., \& Taylor, M. (1994). North-south trade and the environment. The Quarterly Journal of Economics, 3, pp. 755-787.

Dasgupta, S., Huq, M., Wheeler, D., \& Zhang, C. H. (2001). Water pollution abatement by Chinese industry: cost estimates and policy implication. Applied Economics, 33(4), 547-557.

David, M., \& Sinclair-Desgagné, B. (2005). Environmental Regulation and the Eco-Industry. Journal of Regulatory Economics, 28(2), 141-155.

David, M., Nimubona, A., \& Sinclair-Desgagné, B. (2011). Emission taxes and the Market for abatement goods and services. Resource and Energy Economics, 33(1), 179-191.

Feder, G. (1983). On exports and economic growth. Journal of Development Economics, 70(1),1-23. 
Feess, E., \& Muehlheusser, G. (1999). Strategic environmental policy, international trade, and the learning curve: the significance of the environmental industry. Review of Economics, 50(2), 178-194.

Frondel, M., Horbach, J., \& Rennings, K. (2004). End-of-Pipe or Cleaner Production? An Empirical Comparison of Environmental Innovation Decisions Across OECD Countries. Center for European Economic Research in its series ZEW Discussion Papers with number 04-82.

Gray, B. W., \& Deily, E. M. (1996). Compliance and enforcement: Journal of Environmental Economics and Management., 31(1), 96-111.

Gray, B. W., \& Shadbegian, J. R. (2004). 'Optimal' pollution abatement-whose benefits matter,and how much? Journal of Environmental Economics and Management, 47(3), 510534.

Greaker, M. (2004). Industrial Competitiveness and Diffusion of New Pollution Abatement Technology-a new look at the Porter-hypothesis. Research Department of Statistics Norway in its series Discussion Papers with number 371.

Greaker, M. (2006). Spillovers in the development of new pollution abatement technology: A new look at the Porter-hypothesis. Journal of Environmental Economics and Management, $52(1), 411-420$.

Greaker, M., \& Rosendahl, K. E. (2008). Environmental policy with upstream pollution abatement technology firms. Journal of Environmental Economics and Management, 56(3), 246-259.

He, J. (2006). Pollution haven hypothesis and environmental impacts of foreign direct investment: The case of industrial emission of sulfur dioxide $\left(\mathrm{SO}_{2}\right)$ in Chinese provinces. Ecological Economics, 60(1), 228-245.

Jiang, Yi, and Xiaoting Zheng, 2010, Private Sector Participation and Performance of Urban Water Utilities in the People's Republic of China. No. 237. Asian Development Bank, (11), 1-28

Kesidou, E., \& Demirel, P. (2012). On the drivers of eco-innovations: Empirical evidence from the UK. Research Policy, 41(5), 862-870.

Lan, J., \& Munro, A. (2013). Environmental Compliance and Human Capital: Evidence from Chinese Industrial Firms. Resource and Energy Economics, http://dx.doi.org/10.1016/j.reseneeco.2013.05.003. 
Lan, J., Kakinaka, M., \& Huang, X. (2012). Foreign Direct Investment, Human Capital and Environmental Pollution in China. Environmental and Resource Economics, 51(2), 255-275. Liu, Y., Mol, A., \& Chen, J. (2006). The Development of Environmental Industry in China, Pitfalls and Prospects. In P. Ho, Greening Industries in Newly Industrializing Economies, Asian-Style (Anthropology, Economy \& Society) (pp. 79-106). London: Routledge.

Managi, S., \& Kaneko, S. (2010). Chinese Economic Development and the Environment. Cheltenham: Edward Elgar Publishing Limited.

Mankiw, N. G., \& Whinston, M. D. (1986). Free entry and social inefficiency. Rand Journal of Economics, 17(1), 48-58.

Panayotou, T. (1997). Demystifying the Environmental Kuznets Curve: Turning a Black Box into a Policy Tool. Environment and Development Economics, 2(4), 465-484.

Sinclair-Desgagne, B. (2008). The environmental goods and services industry. International Review of Environmental and Resource Economics, 2(1), 69-99.

Smarzynska, B. K., \& Wei, S. J. (2001). Pollution Havens and Foreign Direct Investment: Dirty Secret or Popular Myth? NBER Working Papers 8465.

State Environmental Protection Adminstration (SEPA). (2003). National Environmental Report.

Stavins, N. R. (2004). The Political Economy of Environmental Regulation. (R. Stavins, Ed.) Edward Elgar Publishing.

Telle, K., \& Larsson, J. (2007). Do environmental regulations hamper productivity growth? How accounting for improvement of plants' environmental performance change the conclusion? Ecological Economics, 61(2-3), 438-445.

U.S. International Trade Commission (UITC) . (2005). Air and Noise Pollution Abatement Services:An Examination of U.S.and Foreign Market with Publication 3761. Washington, DC 20436: United States International Trade Commission.

UITC, U. I. (2005). Air and Noise Pollution Abatement Services:An Examination of U.S.and Foreign Market with Publication 3761. Washington, DC 20436: United States International Trade Commission.

Wang, H. (2002). Pollution regulation and abatement efforts: evidence from China. Ecological Economics, 41(1), 85-94. 
Wang, H., \& Wheeler, D. (1996). Pricing industrial pollution in China : an econometric analysis of the levy system. Policy Research Working Paper Series, 1644.

Wang, J. (2002). Environmental Pollution and Legal Controls During the Opening-up and Reform in China: From the Point of an Environmental Law Professor. Proceeding of Environment and Our Sustainability in the 21st Century: Understanding and Cooperation Between Developed and Developing Countries. University of Nagoya.

Yang, H. C., Tseng, H. Y., \& Cheng, P. C. (2012). Environmental regulations, induced R\&D, and productivity: Evidence from Taiwan's manufacturing industries. Resource and Energy Economics, 34(4), 514-532.

Yu, F. Z. (2006). Development and application of clean coal technology in Mainland China. In X. Z. Zhang, \& Y. Bor (Eds.), Energy Economics and Policy in Mainland China and Taiwan (pp. 6788). Beijing: China Environmental Science Press.

Zhang, X. Z. (2011). Energy and Environmental Policy in China: Towards a Low-Carbon Economy. Cheltenham: Edward Elgar Pub. 
Appendix 1. Data Sources.

\begin{tabular}{|c|c|c|}
\hline Variable & Definitions & Source \\
\hline \multicolumn{3}{|c|}{ Firm level variables } \\
\hline$x$ & $\begin{array}{l}\text { Annual output value of the eco-firm (NT } \\
10,000 \text { Yuan) }\end{array}$ & $\begin{array}{l}\text { China industrial enterprises } \\
\text { database (CIED) }\end{array}$ \\
\hline EXPORT & Annual export delivery value of eco-firm & CIED \\
\hline $\mathrm{RD}$ & $\begin{array}{l}\text { Annual R\&D expenditure of the eco-firm (NT } \\
10,000 \text { yuan) }\end{array}$ & CIED \\
\hline SIZE & Annual number of staff and workers & CIED \\
\hline ADS & $\begin{array}{l}\text { Annual advertising expenditure of the eco-firm } \\
(10,000 \text { Yuan) }\end{array}$ & CIED \\
\hline FOREIGN & $\begin{array}{l}\text { fraction of paid-in capital contributed by foreign } \\
\text { investors }\end{array}$ & CIED \\
\hline HMT & $\begin{array}{l}\text { Fraction of paid-in capital contributed by } \\
\text { Hongkong, Macao and Taiwan investors }\end{array}$ & CIED \\
\hline STATE & $\begin{array}{l}\text { Fraction of paid-in capital contributed by the } \\
\text { state-owned investors }\end{array}$ & CIED \\
\hline COLLECTIVE & $\begin{array}{l}\text { Fraction of paid-in capital contributed by the } \\
\text { collective-owned investors }\end{array}$ & CIED \\
\hline PRIVATE & $\begin{array}{l}\text { Fraction of paid-in capital contributed by private } \\
\text { investors }\end{array}$ & CIED \\
\hline \multicolumn{3}{|c|}{ City level variables } \\
\hline$\Gamma$ & $\begin{array}{l}\text { Stringency of environmental regulations } \\
\text { measured by annual average treatment charges } \\
\text { for industrial wastewater and annual levy for } \\
\text { industrial } \mathrm{SO}_{2} \text { emissions }\end{array}$ & $\begin{array}{l}\text { National Development and } \\
\text { Reform Commission }\end{array}$ \\
\hline A & $\begin{array}{l}\text { Industrial wastewater treatment volume and } \\
\text { industrial } \mathrm{SO}_{2} \text { abatement volume. }\end{array}$ & $\begin{array}{l}\text { Statistical yearbooks of key cities } \\
\text { (2004-2008) ("city yearbook") and } \\
\text { Environment yearbook of key } \\
\text { cities } \quad(2003-2008) \\
\text { ("Environmental yearbook") }\end{array}$ \\
\hline $\mathrm{E}$ & $\begin{array}{l}\text { Annual total industrial emissions in terms of } \\
\text { industrial wastewater emissions and industrial } \\
\mathrm{SO}_{2} \text { emission (NT 10,000tons for wastewater, NT } \\
\text { ton for } \mathrm{SO}_{2} \text { ) }\end{array}$ & $\begin{array}{l}\text { City Yearbook, Environment } \\
\text { yearbook }\end{array}$ \\
\hline$E^{\text {net }}$ & $\begin{array}{l}\text { The value of E-A, annual emission emitted after } \\
\text { abatement in terms of industrial SO2 and } \\
\text { industrial wastewater }\end{array}$ & $\begin{array}{l}\text { City Yearbook, } \\
\text { yearbook }\end{array}$ \\
\hline transcost & Annual total volume of freight (10,000 tons) & City Yearbook \\
\hline CAPstock & $\begin{array}{l}\text { Annual Industrial fixed asset stock } 10^{9} \text { Yuan, } \\
\text { adjusted by1990 price of key cities }\end{array}$ & City Yearbook \\
\hline INDemp & Workers employed in industrial sector & City Yearbook \\
\hline $\mathrm{HCl}$ & $\begin{array}{l}\text { industrial average wage paid to staff (human } \\
\text { capital intensity) }\end{array}$ & City Yearbook \\
\hline Hedu & Ratio of college educated and above population & City Yearbook \\
\hline TECH & $\begin{array}{l}\text { Annual scientific and technological expenditure } \\
\text { by local government and enterprises. }\end{array}$ & City Yearbook \\
\hline $\begin{array}{l}\text { POPdensity } \\
\text { Unemp }\end{array}$ & $\begin{array}{l}\text { Population density per } \mathrm{km}^{2} \\
\text { Annual unemployment rate \%o }\end{array}$ & $\begin{array}{l}\text { City Yearbook } \\
\text { City Yearbook }\end{array}$ \\
\hline
\end{tabular}

\footnotetext{
${ }^{5}$ The industrial abatement includes both end-of-pipe abatement and cleaner production abatement.
} 